\title{
Peripartum infection with Streptococcus uberis but not coagulase- negative staphylococci reduced milk production in primiparous cows
}

\author{
L. J. Pearson, J. H. Williamson, ${ }^{1}$ S.-A. Turner, S. J. Lacy-Hulbert, and J. E. Hillerton \\ DairyNZ Ltd., Private Bag 3221, Hamilton 3240, New Zealand
}

\begin{abstract}
The effect of an intramammary infection (IMI) at calving on the milk yield of heifers during their first 200 $\mathrm{d}$ in milk (DIM) was estimated by comparing monozygotic twins, where one member had a naturally occurring IMI detected at the first milking after calving and the other twin did not. Data collected weekly over a full lactation for 29 twin pairs were used to estimate the effects of a peri-calving Streptococcus uberis IMI on milk yield and composition. Data for 19 twin pairs were used to estimate the effects of pericalving coagulase-negative staphylococci (CNS) IMI. A heifer with a Strep. uberis IMI produced $200 \mathrm{~kg}(7 \%)$ less milk during the first 200 $\mathrm{d}$ of lactation compared with her uninfected twin, with significant differences evident throughout the 200-d period. Similar milk losses were recorded for heifers that developed CM or remained subclinical. An elevated milk SCC for infected heifers was only apparent for the first month (d 2-30), although SCC tended to remain high during the second (d 31-60) and third (d 61-90) months. Milk protein concentrations were greater in the Strep. uberis-infected twin over the 200-d period, whereas fat and lactose concentrations showed little change. An IMI caused by Strep. uberis was associated with a lower milk yield, whereas an IMI by CNS was not, despite CNS-infected twins having a higher SCC than their uninfected twin for the first $30 \mathrm{~d}$ of lactation.

Key words: Streptococcus uberis, coagulase-negative staphylococci, mastitis, milk loss
\end{abstract}

\section{INTRODUCTION}

Streptococcus uberis is a common cause of clinical mastitis (CM) in pasture-based dairy herds, with a high prevalence in heifers at calving (McDougall, 2002; Compton et al., 2007) and a reported incidence of CM ranging from 8.1 to $23.4 \%$ of heifers at calving (Pankey et al., 1996). Mastitis during first lactation, when a heifer's udder is completing development, may cause a

Received March 5, 2012.

Accepted September 24, 2012.

${ }^{1}$ Corresponding author: john.williamson@dairynz.co.nz long-term reduction in milk yield when heifers are infected with any major pathogens (Piepers et al., 2009) or Staphylococcus aureus only (Woolford et al., 1983). However, the consequences of a streptococcal infection on milk production are uncertain. Clinical IMI due to environmental streptococci in heifers at calving were associated with only small short-term milk yield losses lasting $1 \mathrm{wk}$ (Gröhn et al., 2004). In contrast, milk yield losses lasting more than $70 \mathrm{~d}$ were reported for cows of parity 2 or greater that developed a streptococcal IMI later in lactation (Gröhn et al., 2004). Consistent with this long-term effect, Wilson et al. (2004) estimated milk production losses to be $690 \mathrm{~kg}$ for first-lactation animals with $\mathrm{CM}$ compared with nonmastitic herd mates. However, as the bacteria associated with the $\mathrm{CM}$ in this study were not stated, extrapolation to the effects of Strep. uberis is difficult.

Estimating true milk yield losses associated with pericalving mastitis in heifers is hampered by the lack of milk yield data preceding the infection event; that is, no previous lactation and absence of a suitable homogeneous control animal. Multiparous cows that develop a streptococcal IMI tend to be higher milk producers before they became infected (Gröhn et al., 2004), so herd mates tend to be an unsuitable model for determining milk yield loss associated with IMI. It is possible that heifers with the potential for higher milk production are also more at risk (Gröhn et al., 1995); therefore, milk yield losses associated with infection around calving may be underestimated.

Coagulase-negative staphylococci are the most common bacteria isolated from heifers pericalving (Fox, 2009) and from subclinical mastitis in well-managed, low SCC herds (Eberhart et al., 1987; Hogan et al., 1989). A multiple herd survey in New Zealand (Pankey et al., 1996) identified that the prevalence of CNS varied from $22 \%$ of heifers at calving to $16 \%$ at dry-off. Infected quarters had a 2- to 3-fold higher SCC than uninfected quarters, but the effect of CNS on milk production was not reported.

The available data on the effect of CNS IMI pericalving on milk SCC and production in heifers are conflicting. Timms and Schultz (1987) concluded that animals with CNS infection had a significantly higher quarter 
SCC and lower milk production (11\% over 305 DIM compared with uninfected animals). Similarly, Gröhn et al. (2004) reported a slight but consistent yield loss for heifers with a CNS infection detected at calving. However, others report small increases in SCC and slightly higher milk production in heifers infected with CNS, compared with their culture-negative herd mates (Schukken et al., 2009; Piepers et al., 2010).

This study used monozygotic twins to determine the effect of a naturally occurring IMI by Strep. uberis or CNS at calving on heifer milk production and SCC up to the first $200 \mathrm{~d}$ in lactation. Monozygotic twins provide an ideal model for examining the effect of a naturally occurring mastitis on milk production and SCC (Roche, 2003). Their identical genetic makeup minimizes cow-to-cow variation within a twin pair, and common rearing and grazing practices in the same location further reduce errors relating to confounding factors such as BW or environmental bacterial challenge. Studying twins allows the use of fewer animals to examine associations between variables than would normally be required to achieve sufficient statistical power.

We hypothesized that those twins infected with Strep. uberis at calving would have a lower milk production than their uninfected twin, whereas milk production would not differ between twins infected with CNS or free from infection at calving.

\section{MATERIALS AND METHODS}

The effect of an IMI detected at the first milking after calving on milk production and SCC was investigated using data from 96 first-lactation heifers (48 twin pairs) between 2004 and 2010, where one twin developed an infection and the other twin remained uninfected for at least the first $200 \mathrm{~d}$ of lactation. The cows were Friesian, Jersey, or Friesian-Jersey crossbreds and were managed in a rotational grazing system at the DairyNZ Lye Farm (Hamilton, New Zealand).

\section{Animals}

The monozygotic herd is maintained by acquiring identical twin calves from producers at approximately 1 mo of age and rearing them together as dairy heifer replacements. Heifers first calve in spring at approximately $2 \mathrm{yr}$ of age. The twin herd is managed as a single herd of up to 150 cows (75 twin pairs) and rotationally grazed on ryegrass-dominant pasture. Cows are supplemented with silage in times of feed deficit. For the animals used in the study, peak milk production averaged $18 \mathrm{~L} / \mathrm{d}$, total production averaged $160 \mathrm{~kg}$ of milk fat and $140 \mathrm{~kg}$ of milk protein across 275 DIM, and BW averaged $400 \mathrm{~kg}$.

\section{Measurements}

After calving cows were milked twice daily at 0700 and $1530 \mathrm{~h}$, and milk yields determined, on a per milking basis, using an electronic milk yield recording and herd management system (Westfalia-Surge Metatron version 5.0, GEA Farm Technology, Bönen, Germany). Total milk produced during each 7 -d period was divided by 7 to provide an average daily milk yield. Proportional milk samples were collected from consecutive afternoon and morning milkings once each week and pooled to provide a composite 24 -h sample. Fat, protein, and lactose contents were determined using an infrared spectrophotometric technique (Milkoscan, Foss Electric, Hillerød, Denmark), and milk SCC was determined using an electronic fluorometric cell counting technique (Fossomatic, Foss Electric).

Single foremilk samples were collected aseptically from each quarter of all heifers at the first milking after calving, once between wk 12 and 16 (peak lactation), once between wk 26 and 30 (mid to late lactation), at dry off, and upon diagnosis of CM. Bacterial culture was conducted on samples according to guidelines of the National Mastitis Council (Hogan et al., 1999). For the purposes of this study, a quarter was defined as infected if it was diagnosed as having a CM or fitted the definition of IMI as described by Torres et al. (2009) for single foremilk samples; that is, isolation of a single bacterial species $\geq 100 \mathrm{cfu} / \mathrm{mL}$ for a major contagious pathogen (Staphylococcus aureus) or $\geq 1,000 \mathrm{cfu} / \mathrm{mL}$ for a major environmental pathogen or minor pathogen.

\section{Mastitis Management}

Diagnosis of glands with CM was based on visible changes to the milk (e.g., clots or flecks), changes in the udder tissues (e.g., heat or swelling of the gland), or both. All clinical cases of mastitis were typically treated with a full course of intramammary antibiotics (Orbenin LA, Pfizer Animal Health Group, Mt. Eden, Auckland, New Zealand). Heifers treated with antibiotics were separated from the main herd until completion of the antibiotic withholding period (up to $12 \mathrm{~d}$ ).

\section{Inclusion Criteria}

Streptococcus uberis-infected twin pairs $(\mathrm{n}=29$ pairs) were selected if one twin was infected with Strep. uberis in one or more glands at the first milking after calving, and her twin sister was free from Strep. uberis 
IMI at the sample times and not diagnosed with $\mathrm{CM}$ throughout lactation. Of these 29 pairs, 11 pairs had one member diagnosed with a CM episode due to Strep. uberis within $14 \mathrm{~d}$ of calving.

Coagulase-negative streptococci-infected twin pairs ( $\mathrm{n}=19$ pairs) were selected if one twin was infected with CNS in one or more quarters at the first milking after calving and her twin sister was free from CNS IMI and major pathogen infections throughout lactation.

\section{Statistics}

Data were analyzed in weekly, monthly, and 200-d periods. Milk SCC data were $\log _{10}$ transformed (Ali and Shook, 1980) before analysis. The effect of IMI at calving on milk production and composition was analyzed using mixed models, with infection as a fixed effect and twin pair and heifer within twin pair as random effects.

Repeated measurements through time were modeled using spline models within the linear mixed model framework, as described by Verbyla et al. (1999). Infection status, linear trend of week, and their interaction were included as fixed effects, and twin-pair, cow within twin-pair, linear trend of week within cow, splines, and the interaction of infection status with spline were included as random effects. Residual maximum likelihood (REML) in GenStat 13.1 (VSN International, Hemel Hempstead, UK) was used to fit all models.

\section{RESULTS}

All except 1 of the 29 Strep. uberis-infected twin pairs were free from Strep. uberis infection by the peak lactation sampling time. Twin members infected with Strep. uberis produced less milk per day than their uninfected twin during d 2 to 200 of lactation (Figure 1A), with differences apparent at each of the monthly intervals examined (Table 1). Heifers with Strep. uberis IMI but no clinical signs (subclinical mastitis only; $\mathrm{n}=18$ pairs) produced less milk per day than their uninfected twin (Table 1). Heifers detected with Strep. uberis CM ( $\mathrm{n}=11$ pairs $)$ also produced less milk compared with their uninfected twin during d 2 to 200 of lactation, but these differences were only significant in the fourth month after calving (d 91-120). When milk yield differences were summed over $200 \mathrm{~d}$, infected twins were found to have produced $200 \mathrm{~kg}$ less milk than their uninfected twin counterparts, with uninfected twins producing $3,119 \mathrm{~kg}$ compared with $2,919 \mathrm{~kg}$ for infected twins $(P<0.001)$.

Milk SCC during the first month postcalving was higher among heifers with a Strep. uberis infection at calving compared with the uninfected twin $(P<0.001$, Figure $1 \mathrm{~B})$ and tended $(P=0.1)$ to remain higher in the second (d 31-60) and third (d 61-90) months after calving (Table 2). Although differences were no longer apparent after the third month, average SCC was higher $(P=0.06)$ over the entire period $(\mathrm{d} 2-200)$. Differences in SCC of those heifers with a subclinical Strep. uberis IMI (IMI only, $\mathrm{n}=18$ pairs) compared with their uninfected twins followed the same pattern as for the whole heifer group. However, no differences in SCC were found when one twin was detected with a Strep. uberis CM ( $\mathrm{n}=11$ pairs). No effect of Strep. uberis infection on milk fat concentration was found and only a minimal effect on milk lactose was found during the first month (d 2-30; Table 3). In comparison, milk protein concentration was higher over $200 \mathrm{~d}$ after calving $(P<0.05)$.

Of the 19 twin sets diagnosed with a CNS IMI at calving, 17 twin members had a single quarter infected and 2 heifers had 2 quarters infected with CNS. By the peak lactation sampling, only 7 animals remained infected. Milk yields of heifers infected with CNS at calving were not different (Figure 1C) over $200 \mathrm{~d}$ of lactation, with the uninfected twin producing a total of $2,909 \mathrm{~kg}$ compared with $2,858 \mathrm{~kg}$ for the infected twins $(P>0.1$; Table 4$)$. In contrast, SCC was higher in twins with a CNS infection at calving (Figure 1D) during the first $30 \mathrm{~d}(P<0.01)$ and over the 200 -d lactation $(P<0.05$; Table 4$)$. No differences in milk fat, protein, or lactose concentrations were found between the CNS infected and uninfected heifer pairs (data not presented).

\section{DISCUSSION}

This study supported the hypothesis that heifers infected with Strep. uberis in the pericalving period have a lower milk yield, with a $7 \%(200-\mathrm{kg})$ reduction in the Strep. uberis-infected twins over $200 \mathrm{~d}$ compared with the uninfected twin. This is in contrast to previous estimates that suggest that a pericalving Strep. uberis IMI has little or no adverse effect on milk yield in heifers $(0$ to $18 \mathrm{~kg}$ per lactation; Gröhn et al., 2004; Compton et al., 2007).

Reasons for the higher estimates of milk yield losses in this study could include the following:

(1) The use of genetically identical twins instead of unrelated animals, which is likely to have reduced the error associated with detecting small differences between treatments. Hancock (1954) determined that monozygotic twins could replace as many as 22 unrelated pairs of animals in estimates of treatment effects on milk volume;

(2) The use of daily measurements of milk yield throughout lactation rather than less frequent 

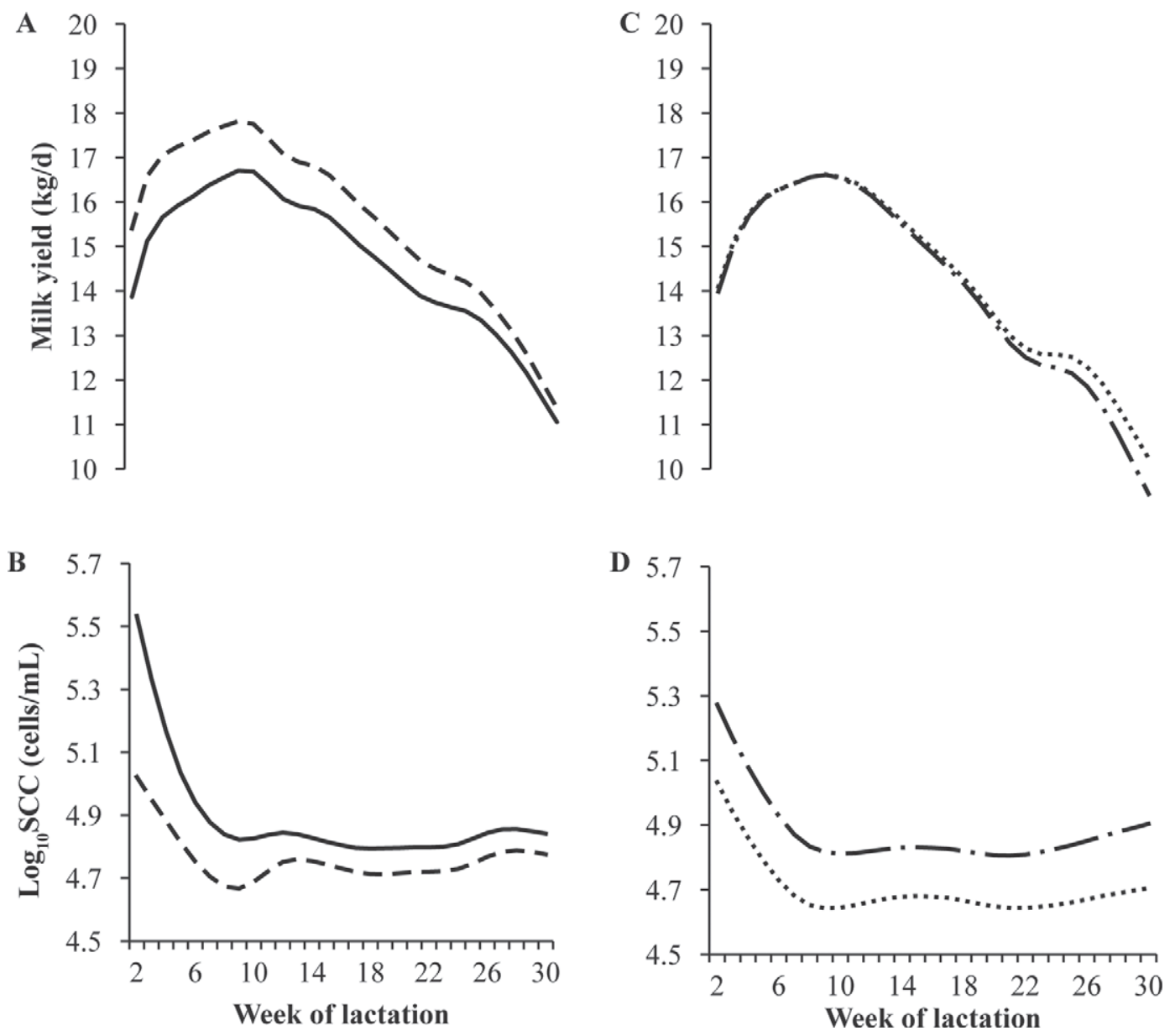

Figure 1. Smoothed splines fitted to (A) milk yield and (B) milk SCC $\left(\log _{10}\right)$ for 29 twin pairs where one twin was free from infection at calving (dashed line), and the other had a Strep. uberis infection at calving (solid line), and (C) milk yield and (D) milk SCC (log 10 ) for 19 twin pairs where one was free from infection at calving (dotted line) and the other had an infection with CNS at calving (dashed-dotted line).

yield assessments (i.e., 4 times during lactation as in Compton et al., 2007), providing a more accurate assessment of short-term changes in milk yield;

(3) The use of regular bacteriological analysis to provide a more stringent definition of infected and uninfected status, enabling subclinically infected animals to be distinguished from uninfected animals.

The previous studies used $\mathrm{CM}$ as the definition of infection and did not account for the presence of subclinical IMI among control animals (Gröhn et al., 2004; Compton et al., 2007). The latter study reported that $10 \%$ of heifer quarters were diagnosed with Strep. uberis IMI at calving, with approximately $45 \%$ of these infections subsequently developing into a clinical episode. In the study reported here, IMI in the absence of CM signs also had a detrimental effect on milk yields. Studies that ignore the intramammary status of control animals may underestimate the difference in milk yield between animals with CM compared with animals presumed to be uninfected.

Other factors that may have contributed to the difference in milk losses reported between studies include differing virulence of pathogenic strains causing the IMI and variation in heifer milk production and lactation length. Nevertheless, the results presented here indicate that peripartum Strep. uberis IMI in heifers is associated with a significant reduction in potential milk yield, and this should be included in calculations of the true costs of heifer mastitis.

Over the 200-d period, heifers with a Strep. uberis infection, whether clinical or not, showed significant losses in milk production. The timing of cure was not established in this study but, in all but one quarter, infections were not detected at the peak lactation sampling. Elevated milk SCC was evident for the first 2 mo after calving in heifers that had been detected with subclinical Strep. uberis mastitis, whereas a minimal ef- 
Table 1. Mean daily milk yield (kg/d) of 29 twin pairs (all) where one twin was free from infection at calving (uninfected) and the other had a Streptococcus uberis infection (infected), for 30-d periods and across d 2 to 200 of lactation, as well as for the twin pairs in which the infected twin was not diagnosed with clinical mastitis (IMI only, $\mathrm{n}=18)$ or was diagnosed with clinical mastitis $(\mathrm{CM}, \mathrm{n}=11)$ within $14 \mathrm{~d}$ of calving

\begin{tabular}{lcccc}
\hline $\begin{array}{l}\text { Group/day } \\
\text { of lactation }\end{array}$ & Uninfected & Infected & SED $^{1}$ & $P$-value \\
\hline All & & & & \\
2 to 30 & 15.6 & 14.0 & 0.33 & $<0.001$ \\
31 to 60 & 17.5 & 16.3 & 0.30 & $<0.001$ \\
61 to 90 & 17.4 & 16.4 & 0.25 & $<0.001$ \\
91 to 120 & 16.5 & 15.5 & 0.16 & $<0.001$ \\
2 to 200 & 15.8 & 14.7 & 0.18 & $<0.001$ \\
& & & & \\
IMI only & 16.7 & 14.9 & 0.33 & $<0.001$ \\
2 to 30 & 18.6 & 17.3 & 0.36 & 0.002 \\
31 to 60 & 18.7 & 17.5 & 0.35 & 0.003 \\
61 to 90 & 17.6 & 16.5 & 0.22 & $<0.001$ \\
91 to 120 & 16.8 & 15.6 & 0.21 & $<0.001$ \\
2 to 200 & & & & \\
& & & & \\
CM & 13.7 & 12.6 & 0.69 & 0.14 \\
2 to 30 & 15.7 & 14.7 & 0.54 & 0.074 \\
31 to 60 & 15.3 & 14.6 & 0.35 & 0.065 \\
61 to 90 & 14.8 & 13.9 & 0.23 & 0.003 \\
91 to 120 & 14.0 & 13.3 & 0.33 & 0.045 \\
2 to 200 & & & & \\
\hline
\end{tabular}

${ }^{1} \mathrm{SED}=$ standard error of the difference.
Table 3. Concentrations (\%) of fat, protein, and lactose in the milk of 29 twin pairs where one twin was free from infection at calving (uninfected) and the other had a Streptococcus uberis infection (infected), for each 30-d period and across d 2 to 200 of lactation

\begin{tabular}{lcccl}
\hline $\begin{array}{l}\text { Item/day } \\
\text { of lactation }\end{array}$ & Uninfected & Infected & SED $^{1}$ & $P$-value \\
\hline Fat & & & & \\
2 to 30 & 5.35 & 5.33 & 0.06 & 0.79 \\
31 to 60 & 4.85 & 4.88 & 0.07 & 0.68 \\
61 to 90 & 4.69 & 4.76 & 0.06 & 0.28 \\
91 to 120 & 4.70 & 4.75 & 0.04 & 0.23 \\
2 to 200 & 4.87 & 4.92 & 0.03 & 0.10 \\
& & & & \\
Protein & 3.69 & 3.74 & 0.03 & 0.14 \\
2 to 30 & 3.42 & 3.46 & 0.02 & 0.087 \\
31 to 60 & 3.59 & 3.65 & 0.02 & 0.004 \\
61 to 90 & 3.70 & 3.73 & 0.02 & 0.10 \\
91 to 120 & 3.64 & 3.68 & 0.01 & 0.016 \\
2 to 200 & & & & \\
& & & & \\
Lactose & 5.02 & 4.98 & 0.02 & 0.051 \\
2 to 30 & 5.06 & 5.09 & 0.03 & 0.40 \\
31 to 60 & 5.00 & 4.99 & 0.02 & 0.53 \\
61 to 90 & 4.97 & 4.97 & 0.01 & 0.88 \\
91 to 120 & 4.97 & 4.97 & 0.01 & 0.82 \\
2 to 200 & & & \\
\hline
\end{tabular}

${ }^{1} \mathrm{SED}=$ standard error of the difference.

fect on SCC beyond the first $30 \mathrm{~d}$ after calving was observed in heifers with clinical signs. This would suggest that antibiotic treatment aided the speed of recovery from infection, but was not sufficient to offset milk production losses associated with a clinical episode. Milner et al. (1997) reported more rapid recovery in SCC and milk yields for IMI caused by Strep. uberis with early intervention with antibiotics. Further studies are required to determine the full benefits of prompt treatment of clinical and subclinical IMI by

Table 4. Mean daily milk yield $(\mathrm{kg} / \mathrm{d})$, and $\log _{10}$ SCC of 19 twin pairs where one twin was free from infection (uninfected) and the other twin had a CNS infection at calving (infected) for each 30-d period and across d 2 to 200 of lactation

\begin{tabular}{lcccc}
$\begin{array}{l}\text { Item/day } \\
\text { of lactation }\end{array}$ & Uninfected & Infected & SED $^{1}$ & $P$-value \\
\hline $\begin{array}{l}\text { Milk yield } \\
2 \text { to } 30\end{array}$ & 14.5 & 14.3 & 0.67 & 0.78 \\
31 to 60 & 16.3 & 16.5 & 0.61 & 0.79 \\
61 to 90 & 16.5 & 16.3 & 0.53 & 0.81 \\
91 to 120 & 15.4 & 14.9 & 0.56 & 0.37 \\
2 to 200 & 14.7 & 14.4 & 0.46 & 0.59 \\
& & & & \\
$\log _{10}$ SCC & 4.88 & 5.25 & 0.09 & 0.002 \\
2 to 30 & 4.74 & 4.91 & 0.11 & 0.13 \\
31 to 60 & 4.68 & 4.83 & 0.09 & 0.087 \\
61 to 90 & 4.68 & 4.84 & 0.10 & 0.12 \\
91 to 120 & 4.70 & 4.89 & 0.08 & 0.032 \\
2 to 200 & & & & \\
\hline
\end{tabular}

${ }^{1} \mathrm{SED}=$ standard error of the difference.

${ }^{1} \mathrm{SED}=$ standard error of the difference. 
Strep. uberis for heifers over a complete lactation and the value proposition of culturing milk from heifers to identify subclinical cases.

Higher milk protein concentrations over the 200-d period were detected in the milk of the infected twin. This is consistent with changes in protein concentration observed in mid-lactation cows following establishment of a clinical Strep. uberis infection (Lacy-Hulbert et al., 1996).

The moderately higher SCC observed during the first month of lactation for heifers affected by a CNS IMI were consistent with previous studies (Compton et al., 2007; Piepers et al., 2010). However, the lack of effect on milk production or composition may help shed light on the hypothesis of Compton et al. (2007), that the small yield advantages reported for CNS (Schukken et al., 2009; Piepers et al., 2010) may actually reflect a greater susceptibility of higher producing heifers to CNS infection compared with unrelated herd mates. Although CNS are the most common cause of pericalving IMI in New Zealand dairy herds, our results confirm that CNS infections rarely affect milk yield.

Duplicate foremilk samples are generally considered the gold standard for determining infection status, especially for cows with clinical or subclinical mastitis (Oliver et al., 2004). However, such samples were not available for this study; it is possible that use of single samples led to the inclusion of some twin pairs that were not truly infected with CNS, as these bacteria are commonly associated with teat skin flora (Hogan et al., 1999). However, Dohoo et al. (2011) found that triplicate samples collected within a 2 -d period provided little improvement in specificity and sensitivity compared with collection of single samples. In the same study, duplicate samples provided only marginal improvements in specificity for Streptococcus spp., from 95 to $99 \%$, and for CNS infections, from 84 to $97 \%$. This was at the expense of sensitivity, which reduced from 29 to $<12 \%$ for Streptococcus spp., and from 61 to $<50 \%$ for CNS.

In field investigations where prevalence of infection is determined across a large number of potentially uninfected animals, single samples are a more practical and cost-effective option. A lower specificity can be tolerated to maximize sensitivity, and use of higher thresholds (i.e., cfu $/ \mathrm{mL}$ ) to interpret culture results can improve the accuracy of diagnosis. In a study of 560 late-lactation animals, across duplicate samples with 5 different IMI definitions, Torres et al. (2009) concluded that bovine IMI could be accurately determined from single samples if a threshold of $\geq 100 \mathrm{cfu} / \mathrm{mL}$ was used for contagious pathogens, and $\geq 1,000 \mathrm{cfu} / \mathrm{mL}$ for major environmental and minor pathogens. Thus, this definition was used for this study.

\section{CONCLUSIONS}

The ability to use monozygotic twins provided a unique opportunity to determine the effect of IMI resulting from Strep. uberis and CNS on milk production and SCC. Twins with Strep. uberis IMI pericalving produced $7 \%$ less milk than their uninfected twin counterparts, irrespective of whether the heifer developed $\mathrm{CM}$ or remained subclinical. Moderate elevations in SCC were detected for the first month after calving for heifers with a Strep. uberis IMI pericalving. For heifers infected with CNS pericalving, we observed no effects on milk production but the SCC showed moderate elevations for the first month after calving.

\section{ACKNOWLEDGMENTS}

The authors are grateful to the DairyNZ Lye Farm staff (Hamilton, New Zealand) for care of the twins, milk sampling, and data collection, and to Barbara Dow (DairyNZ) for statistical assistance. Funding was from New Zealand dairy farmers through DairyNZ Ltd. (AN713).

\section{REFERENCES}

Ali, A. K. A., and G. E. Shook. 1980. An optimum transformation for somatic cell concentration in milk. J. Dairy Sci. 63:487-490.

Compton, C. W., C. Heuer, K. Parker, and S. McDougall. 2007. Epidemiology of mastitis in pasture-grazed peripartum dairy heifers and its effects on productivity. J. Dairy Sci. 90:4157-4170.

Dohoo, I., S. Andersen, R. Dingwell, K. Hand, D. Kelton, K. Leslie, Y Schukken, and S. Godden. 2011. Diagnosing intramammary infections: Comparison of multiple versus single quarter milk samples for the identification of intramammary infections in lactating dairy cows. J. Dairy Sci. 94:5515-5522.

Eberhart, R. J., R. J. Harmon, D. E. Jasper, R. P. Natzke, S. C. Nickerson, J. K. Reneau, E. H. Row, K. L. Smith, and S. B. Spencer. 1987. Current Concepts of Bovine Mastitis. 3rd ed. NMC Inc., Arlington, VA.

Fox, L. K. 2009. Prevalence, incidence and risk factors of heifer mastitis. Vet. Microbiol. 134:82-88.

Gröhn, Y. T., S. W. Eicker, and J. A. Hertl. 1995. The association between previous 305-day milk yield and disease in New York State dairy cows. J. Dairy Sci. 78:1693-1702.

Gröhn, Y. T., D. J. Wilson, R. N. Gonzalez, J. A. Hertl, H. Schulte, G. Bennett, and Y. H. Schukken. 2004. Effect of pathogen-specific clinical mastitis on milk yield in dairy cows. J. Dairy Sci. $87: 3358-3374$.

Hancock, J. 1954. Monozygotic twins in cattle. Advances in Genetics. Vol. VI. Academic Press Inc., New York, NY.

Hogan, J., R. Gonzalez, R. Harmon, S. Nickerson, S. Oliver, J. Pankey, and K. Smith. 1999. Laboratory Handbook on Bovine Mastitis. National Mastitis Council Inc., Madison, WI.

Hogan, J. S., K. L. Smith, K. H. Hoblet, P. S. Schoenberger, D. A. Todunter, W. D. Hueston, D. E. Prichard, G. L. Bowman, L. E. Heider, B. L. Brockett, and H. R. Conrad. 1989. Field survey of clinical mastitis in low somatic cell count herds. J. Dairy Sci. 72:1547-1556. 
Lacy-Hulbert, S., M. Woolford, L. Nichloas, and K. Stelwagen. 1996. Effect of Streptococcus uberis infection on milk characteristics of individual quarters. Proc. N. Z. Soc. Anim. Prod. 56:65-67.

McDougall, S. 2002. Bovine mastitis: Epidemiology, treatment and control. N. Z. Vet. J. 50(Suppl.):81-84.

Milner, P., K. L. Page, and J. E. Hillerton. 1997. The effects of early antibiotic treatment following diagnosis of mastitis detected by a change in the electrical conductivity of milk. J. Dairy Sci. 80:859 863.

Oliver, S. P., R. N. Gonzalez, J. S. Hogan, B. M. Jayarao, and W. E. Owens, ed. 2004. Microbiological Procedures for the Diagnosis of Bovine Udder Infection and Determination of Milk Quality. 4th ed. National Mastitis Council Inc., Verona, WI.

Pankey, J. W., P. B. Pankey, R. M. Barker, J. H. Williamson, and M. W. Woolford. 1996. The prevalence of mastitis in primiparous heifers in eleven Waikato dairy herds. N. Z. Vet. J. 44:41-44

Piepers, S., S. De Vliegher, A. de Kruif, G. Opsomer, and H. W Barkema. 2009. Impact of intramammary infections in dairy heifers on future udder health, milk production, and culling. Vet. Microbiol. 134:113-120.

Piepers, S., G. Opsomer, H. W. Barkema, A. de Kruif, and S. De Vliegher. 2010. Heifers infected with coagulase-negative staphylococci in early lactation have fewer cases of clinical mastitis and higher milk production in their first lactation than noninfected heifers. J. Dairy Sci. 93:2014-2024.
Roche, J. R. 2003. Effect of pregnancy on milk production and bodyweight from identical twin study. J. Dairy Sci. 86:777-783.

Schukken, Y. H., R. N. Gonzalez, L. L. Tikofsky, H. F. Schulte, C. G. Santisteban, F. L. Welcome, G. J. Bennett, M. J. Zurakowski, and R. N. Zadoks. 2009. CNS mastitis: Nothing to worry about? Vet. Microbiol. 134:9-14.

Timms, L. L., and L. H. Schultz. 1987. Dynamics and significance of coagulase negative staphylococcal intramammary infections. J. Dairy Sci. 70:2648-2657.

Torres, A. H., P. J. Rajala-Schultz, and F. J. DeGraves. 2009. Diagnosis of intramammary infections at dry-off based on sampling strategy, epidemiology of pathogens, and agreement beyond chance. J. Vet. Diagn. Invest. 21:427-436.

Verbyla, A. P., B. R. Cullis, M. G. Kenward, and S. J. Welham. 1999. The analysis of designed experiments and longitudinal data by using smoothing splines. Appl. Stat. 48:269-311.

Wilson, D. J., R. N. Gonzalez, J. Hertl, H. F. Schulte, G. J. Bennett, Y. H. Schukken, and Y. T. Gröhn. 2004. Effect of clinical mastitis on the lactation curve: A mixed model estimation using daily milk weights. J. Dairy Sci. 87:2073-2084.

Woolford, M., J. H. Williamson, P. J. A. Copeman, A. R. Napper, D. S. M. Phillips, and E. Uljee. 1983. How much does mastitis affect milk production? N. Z. J. Agric. 147:27-34 